\title{
Effect of Controlled Release Fertilizer on Growth, Yield and Quality of Bottle gourd (Lagenaria siceraria Mol.) under Prayagraj Agro-climatic Conditions
}

\author{
Jomel Sebastian*, Samir E. Topno and V. M. Prasad \\ Department of Horticulture, Sam Higginbottom University of Agriculture Technology and \\ Sciences, 211007, U.P., India \\ *Corresponding author
}

\section{A B S T R A C T}

\section{Keywords}

Controlled Release

Fertilizer, Bottle gourd

Article Info

Accepted:

12 March 2021

Available Online:

10 April 2021
The experiment entitled "Effect of Controlled Release Fertilizer on Growth, Yield and Quality of Bottle gourd (Lagenaria siceraria Mol.) under Prayagraj Agro-climatic Conditions" was conducted at Department of Horticulture, Sam Higginbottom University of Agriculture, Technology and Sciences, Prayagraj during February- June 2019. The experiment was laid out in Randomized Block Design having 9 treatments with three replications. The results revealed that the maximum vine length $(8.41 \mathrm{~m})$ was recorded in treatment $7 \mathrm{~g} \mathrm{CRF}$, minimum number of days taken for first female flower appearance (72.24 days) was recorded in treatment $7 \mathrm{~g} \mathrm{CRF}$, maximum number of male flowers per plant (68.08 flowers) was recorded in treatment6 g CRF, maximum number of female flowers per plant (17.55 flowers) was recorded in $7 \mathrm{~g}$ $\mathrm{CRF}$, maximum average fruit length $(38.53 \mathrm{~cm}$ ) was recorded in $7 \mathrm{~g} \mathrm{CRF}$, maximum average fruit weight $(1.25 \mathrm{~kg})$ was recorded in treatment $7 \mathrm{~g} \mathrm{CRF}$, maximum fruit diameter $(22.88 \mathrm{~cm})$ was recorded in $8 \mathrm{~g} \mathrm{CRF}$, maximum number of fruits/plant (11.49 fruits) was recorded in7 $\mathrm{g} \mathrm{CRF}$, maximum fruit yield (57.36 ton per ha) was recorded in7 $\mathrm{g}$ CRF, maximum total soluble solid $\left(5.07^{\circ} \mathrm{Brix}\right)$ was recorded in7 $\mathrm{g}$ CRF, maximum vitamin $\mathrm{C}$ content $(8.39 \mathrm{mg}$ ) was recorded in $8 \mathrm{~g}$ CRF, maximum cost benefit ratio 4.19 , was recorded in treatment7 g CRF.

\section{Introduction}

The Cucurbitaceae family is commonly known as the gourd, melon or pumpkin family. It seems that bottle gourd was originated from India because its wild races are still found in Dehradun (high humid area) and Malabar coastal area (Milind et al., 2011).
Lagenaria siceraria Mol. $(2 \mathrm{n}=22)$ commonly known as bottle gourd has the highest content of choline among all the vegetables known to man till date, which serves as the precursor of neurotransmitter acetylcholine, which in turn is crucial for retaining and enhancing memory (Milind et al., 2011). Furthermore, it is useful in the management of many diseases like 
cardiac disorders, hepatic diseases and ulcer. Bottle gourd juice helps to control blood pressure of hypertensive patient. In the light of the above-mentioned multiple benefits of bottle gourd, it may be regarded as a natural guard against diseases. It is widely cultivated in tropical and pan-tropical regions of the world. In nature, bottle gourd exhibits great morphological and genetic variability and could show wide environmental adaptation (Koffi, 2009). Indian farmers used different local cultivars and released (from different organizations) bottle gourd variety.

Nitrogen $(\mathrm{N})$, phosphorous $(\mathrm{P})$, and potassium (K) are critical nutrient elements for crop plant growth and development, and applying fertilizers, especially $\mathrm{N}$ to crops, is a valuable agronomic practice (Zhao et al., 2013). However, excessive fertilization can result in nutrient inefficiencies and excessive losses of $\mathrm{N}$ and $\mathrm{P}$ in the field environment, and also impact soil, water and air quality, human health, and biodiversity (Goulding et al., 2008). Interventions to increase fertilizer usage efficiency (FUE) and reduce nutrient inputs, especially $\mathrm{N}$, are of significant importance for reducing environmental loading and lowering the costs of agricultural production (Wang et al., 2011).

Controlled-release fertilizer (CRF) is a good alternative to soluble fertilizer (SF) to increase fertilizer usage efficiency and minimize nutrient losses, especially $\mathrm{N}$, in the field environment (Zhao et al., 2013). Controlledrelease fertilizers (CRFs) are granular fertilizer particles that are coated with a polymer or resin that restricts the amount of moisture contact and functions to dissolve the fertilizer particles gradually releasing the nutrients ( $\mathrm{Li}$ et al., 2012). There are three easily identifiable benefits to using CRFs: ease of use, reduction of application costs compared to water-soluble fertilizers, and potential reduction of environmental impact.
A CRF will continuously release fertilizer without the addition of water. It only needs to be applied once, unlike water-soluble fertilizers. The incorporation of a CRF also reduces labour costs. Water-soluble fertilizer run-off is a primary cause of pollution of waterways, green algae bloom and killing of fish. With CRFs, however, once the fertilizer has been incorporated, it cannot be changed. When temperatures are unseasonably warm or cool, the fertilizer may be released too quickly and cause root burn, or dissolve too slowly, causing nutrient deficiencies.

Due to a lack of experience with the field performance of CRF and its high relative cost, current grower acceptance is limited (Zhao et al., 2013). However, the greatest benefits of changing from SF to CRF include not only increased profitability, but also reductions in the environmental pollution of crop production. In view of facts given above to work out the Controlled Release Fertiliser for enhancing the productivity of bottle gourd in Prayagraj region.

\section{Materials and Methods}

A field experiment was conducted at Research Field, Department of Horticulture, Sam Higginbottom University of Agriculture, Technology and Sciences, during February to June 2019. Indigenous variety of bottle gourd from Himachal Pradesh was taken for the experiment. The study was laid out as Randomized Block Design with 9 treatments and 3 replications. Varying dosages of CRF was taken as treatments while recommended dosage of fertilizer was applied for the control. The CRF used in this study is manufactured by NOUSBO and the amount of nutrients (NPK) in the fertilizer is 20:12:16 respectively.

These different parameters were analysedGrowth (vine length (m)), flowering (days to 
first female flower appearance, number of male flower per plant, number of female flower per plant, days to first picking), Yield (average fruit length $(\mathrm{cm})$, average fruit weight $(\mathrm{kg})$, fruit diameter $(\mathrm{cm})$, number of fruits per plant, average yield ton/ha), Fruit quality (TSS ( ${ }^{\mathrm{B}}$ Brix), Vitamin $\mathrm{C} \quad(\mathrm{mg})$ ), Economics (Benefit cost ratio).

\section{Results and Discussion}

Among the treatments the maximum significant vine length $(8.41 \mathrm{~m})$ was recorded in treatment $\mathrm{T}_{7}(7 \mathrm{~g}$ CRF) followed by treatment $\mathrm{T}_{8}(8 \mathrm{~g} \mathrm{CRF})$, while the minimum vine length $(4.30 \mathrm{~m})$ was recorded in treatment $\mathrm{T}_{0}$ (Control). Minimum significant number of days to first female flower appearance (72.24 days) was recorded in treatment $\mathrm{T}_{7}(7 \mathrm{~g} \mathrm{CRF})$ followed by $\mathrm{T}_{8}(8 \mathrm{~g}$ CRF) with (74.22 days) whereas the maximum days taken for appearance of first female flower (88.95 days) was recorded in treatment $\mathrm{T}_{0}(\mathrm{Control})$.

Maximum significant number of male flowers per plant (68.08 flowers) was recorded in treatment $\mathrm{T}_{6}(6 \mathrm{~g} \mathrm{CRF})$ followed by treatments $\mathrm{T}_{8}$ (8 g CRF) with (62.04 flowers), whereas the minimum number of male flowers per plant (38.53 flowers/plant) was recorded in treatment $\mathrm{T}_{0}$ (Control). Among the treatments the maximum significant number of female flowers per plant (17.55 flowers) was recorded in treatment $\mathrm{T}_{7}(7 \mathrm{~g}$ CRF) followed by treatments $\mathrm{T}_{6}(6 \mathrm{~g} \mathrm{CRF})$ with (16.29 flowers), whereas the minimum number of female flowers per plant (7.68 flowers/plant) was recorded in treatment $\mathrm{T}_{0}$ (Control).

Maximum significant average fruit length $(38.53 \mathrm{~cm})$ was recorded in treatment $\mathrm{T}_{7}(7 \mathrm{~g}$ CRF) followed by treatment $\mathrm{T}_{6}(6 \mathrm{~g} \mathrm{CRF})$ with $(35.95 \mathrm{~cm})$ whereas minimum fruit length $(25.51 \mathrm{~cm})$ was recorded in treatment $\mathrm{T}_{0}$ (Control). Maximum significant average fruit weight $(1.25 \mathrm{~kg})$ was recorded in treatment $\mathrm{T}_{7}$ (7 g CRF) followed by treatment $\mathrm{T}_{6} \quad(6 \mathrm{~g}$ CRF $)$ with $(1.22 \mathrm{~kg})$ whereas minimum average fruit weight $(0.86 \mathrm{~kg})$ was recorded in treatment $\mathrm{T}_{0}$ (Control). Maximum significant fruit diameter $(22.88 \mathrm{~cm})$ was recorded in treatment $\mathrm{T}_{8}(8 \mathrm{~g} \mathrm{CRF})$ followed by treatment $\mathrm{T}_{7}(7 \mathrm{~g}$ CRF $)$ with $(21.74 \mathrm{~cm})$ whereas minimum fruit diameter $(13.47 \mathrm{~cm})$ was recorded in treatment $\mathrm{T}_{0}$ (Control).

Maximum significant fruit yield ton/ha (57.36 ton) was recorded in treatment $\mathrm{T}_{7}(7 \mathrm{~g} \mathrm{CRF})$ followed by treatment $\mathrm{T}_{8}(8 \mathrm{~g} \mathrm{CRF})$ with (48.05 ton) whereas minimum fruit yield ton/ha (20.07 ton) was recorded in treatment $\mathrm{T}_{0}$ (Control).

Maximum significant total soluble solid (5.07 ${ }^{\circ}$ Brix) was recorded in treatment $\mathrm{T}_{7}(7 \mathrm{~g} \mathrm{CRF})$ followed by treatment $\mathrm{T}_{8}(8 \mathrm{~g} \mathrm{CRF})$ with (4.83 ${ }^{\circ}$ Brix) whereas minimum total soluble solid (2.61 ${ }^{\circ}$ Brix) was recorded in treatment $\mathrm{T}_{0}$ (Control).

Maximum significant Vitamin C content (8.39 mg) was recorded in treatment $\mathrm{T}_{8}(8 \mathrm{~g} \mathrm{CRF})$ followed by treatment $\mathrm{T}_{7}(7 \mathrm{~g} \mathrm{CRF})$ with $(8.22$ $\mathrm{mg}$ ) whereas minimum vitamin $\mathrm{C}$ content $(5.16 \mathrm{mg})$ was recorded in treatment $\mathrm{T}_{0}$ (Control). The maximum benefit cost ratio 4.19, was recorded in treatment $\mathrm{T}_{7}$ ( $\left.7 \mathrm{~g} \mathrm{CRF}\right)$, followed by treatment $\mathrm{T}_{8}(8 \mathrm{~g} \mathrm{CRF})$ with 3.51 and minimum benefit cost ratio 1.46 was recorded in treatment $\mathrm{T}_{0}$ (control).

Controlled Release Fertilizer, an effective fertilizer encapsulated in polymer coating. It controls leaching and applying it to the root zone ensured that the plant acquires maximum NPK. Labour costs are drastically reduced in $\mathrm{CRF}$ as they are granulated and only one-time application is done for short duration crops. The effectiveness and the application of the particular form of nutrient supplement was submerged due to the unawareness among the farmer class. 
Table.1 Effect of Controlled Release Fertilizer on different parameters in bottle gourd

\begin{tabular}{|c|c|c|c|c|c|c|c|c|c|c|c|c|c|}
\hline $\begin{array}{c}\text { Treatment } \\
\text { symbols }\end{array}$ & $\begin{array}{c}\text { Treatment } \\
\text { combinations }\end{array}$ & $\begin{array}{c}\text { Vine } \\
\text { length } \\
(\mathbf{m})\end{array}$ & $\begin{array}{l}\text { Days to first } \\
\text { female flower } \\
\text { appearance }\end{array}$ & $\begin{array}{c}\text { No. of } \\
\text { male } \\
\text { flower } \\
\text { per } \\
\text { plant }\end{array}$ & $\begin{array}{c}\text { No. of } \\
\text { female } \\
\text { flower } \\
\text { per } \\
\text { plant }\end{array}$ & $\begin{array}{c}\text { Av. } \\
\text { fruit } \\
\text { length } \\
(\mathrm{cm})\end{array}$ & $\begin{array}{c}\text { Av. } \\
\text { Fruit } \\
\text { weight } \\
\text { (kg) }\end{array}$ & $\begin{array}{c}\text { Fruit } \\
\text { diameter } \\
(\mathrm{cm})\end{array}$ & $\begin{array}{c}\text { No. of } \\
\text { fruits } \\
\text { per } \\
\text { plant }\end{array}$ & $\begin{array}{l}\text { Av. } \\
\text { Yield } \\
\text { (t/ha) }\end{array}$ & $\begin{array}{c}\text { TSS } \\
\left({ }^{0} \text { Brix }\right)\end{array}$ & $\begin{array}{l}\text { Vitamin } \\
\text { C (mg) }\end{array}$ & $\begin{array}{c}\text { Benefit } \\
\text { cost } \\
\text { ratio }\end{array}$ \\
\hline $\mathbf{T}_{0}$ & Control (RDF) & 4.30 & 88.95 & 38.53 & 7.68 & 25.51 & 0.860 & 13.47 & 5.88 & 20.07 & 2.61 & 5.16 & 1.46 \\
\hline $\mathbf{T}_{1}$ & $\begin{array}{c}\text { 1g Controlled } \\
\text { Release } \\
\text { Fertilizer (CRF) }\end{array}$ & 6.47 & 81.51 & 48.73 & 9.08 & 32.90 & 0.990 & 17.96 & 7.69 & 30.13 & 2.72 & 6.34 & 2.20 \\
\hline $\mathbf{T}_{2}$ & $\begin{array}{c}2 \mathrm{~g} \text { Controlled } \\
\text { Release } \\
\text { Fertilizer (CRF) }\end{array}$ & 6.48 & 83.48 & 50.11 & 9.55 & 32.69 & 1.02 & 18.47 & 7.41 & 30.30 & 2.65 & 6.07 & 2.21 \\
\hline $\mathbf{T}_{3}$ & $\begin{array}{l}3 \mathrm{~g} \text { Controlled } \\
\text { Release } \\
\text { Fertilizer (CRF) }\end{array}$ & 6.88 & 80.58 & 46.91 & 11.36 & 33.20 & 1.08 & 17.90 & 7.81 & 33.73 & 3.28 & 7.16 & 2.46 \\
\hline $\mathbf{T}_{4}$ & $\begin{array}{l}\text { 4g Controlled } \\
\text { Release } \\
\text { Fertilizer (CRF) }\end{array}$ & 6.07 & 77.50 & 56.53 & 11.54 & 35.36 & 1.14 & 19.06 & 8.78 & 40.01 & 3.63 & 7.34 & 2.92 \\
\hline $\mathbf{T}_{5}$ & $\begin{array}{c}5 \mathrm{~g} \text { Controlled } \\
\text { Release } \\
\text { Fertilizer (CRF) }\end{array}$ & 6.23 & 79.53 & 51.95 & 13.61 & 31.48 & 1.11 & 21.29 & 9.58 & 42.43 & 4.57 & 7.58 & 3.10 \\
\hline$T_{6}$ & $\begin{array}{c}\text { 6g Controlled } \\
\text { Release } \\
\text { Fertilizer (CRF) }\end{array}$ & 7.28 & 74.50 & 68.08 & 16.29 & 34.50 & 1.22 & 21.04 & 9.45 & 46.12 & 4.54 & 7.77 & 3.36 \\
\hline $\mathbf{T}_{7}$ & $\begin{array}{c}7 \mathrm{~g} \text { Controlled } \\
\text { Release } \\
\text { Fertilizer (CRF) }\end{array}$ & 8.41 & 72.24 & 58.21 & 17.55 & 38.53 & 1.25 & 21.74 & 11.49 & 57.36 & 5.07 & 8.22 & 4.19 \\
\hline $\mathbf{T}_{8}$ & $\begin{array}{l}\text { 8g Controlled } \\
\text { Release } \\
\text { Fertilizer (CRF) }\end{array}$ & 7.51 & 74.22 & 62.04 & 15.10 & 35.95 & 1.13 & 22.88 & 10.64 & 48.05 & 4.83 & 8.39 & 3.51 \\
\hline & F-Test & $\mathbf{S}$ & $\mathbf{S}$ & $\mathbf{S}$ & $\mathbf{S}$ & $\mathbf{S}$ & $\mathbf{S}$ & $\mathbf{S}$ & $\mathbf{S}$ & $\mathbf{S}$ & $\mathbf{S}$ & $\mathbf{S}$ & \\
\hline & C.D at $5 \%$ & 0.643 & 2.189 & 1.322 & 0.181 & 1.734 & 0.095 & 1.914 & 1.419 & 0.500 & 0.396 & 0.779 & \\
\hline & S.Ed ( $( \pm)$ & 0.303 & 1.033 & 0.624 & 0.085 & 0.818 & 0.045 & 0.903 & 0.670 & 0.234 & 0.187 & 0.367 & \\
\hline
\end{tabular}


According to the experimental results, controlled release fertilizer has rendered its significant effect on indigenous variety of bottle gourd from Himachal Pradesh. While considering all parametersexcept vitamin $\mathrm{C}$, dosage of $7 \mathrm{~g}$ of $\mathrm{CRF}\left(\mathrm{T}_{7}\right)$ was found to be the best when compared with other treatments and control. Treatment $\mathrm{T}_{8}(8 \mathrm{~g}$ CRF $)$ recorded subsequent values for growth, flowering, yield and quality with maximum vitamin $\mathrm{C}$ content. The maximum benefit cost ratio (4.19) was recorded in treatment $\mathrm{T}_{7}(7 \mathrm{~g} \mathrm{CRF})$ followed by treatment $\mathrm{T}_{8}$ ( $\left.8 \mathrm{~g} \mathrm{CRF}\right)$ (3.51). Thus, it is concluded that the treatment $\mathrm{T}_{7}(7 \mathrm{~g}$ Controlled Release Fertilizer) was suitable for application in bottle gourd cultivation for better yield $\left(57.36 \mathrm{t} \mathrm{ha}^{-1}\right)$. However, treatment $\mathrm{T}_{8}$ (8 g Controlled Release Fertilizer) was comparable.

\section{References}

Goulding, K., Jarvis, S. and Whitmore, A. (2008). Optimizing nutrient management for farm systems. Philosophical Transactions of the Royal Society B: Biological Sciences, Vol. 363(1491), 667-680.

Guertal, E. A. (2009). Slow-release nitrogen fertilizers in vegetable production: a review. Hort Technology, Vol. 19(1), 16-19.

Koffi, K. K., Anzara, G. K., Malice, M., Dje, Y., Bertin, P., Baudoin, J. and Zoro, Bi I. A. (2009).Morphological and allozyme variation in a collection of Lagenaria siceraria (Molina) Standl. from Cote d'Ivoire. Biotechnol. Agron. Soc. Environ., Vol. 13(2), 257-270.

Li, Q., Wu, S., Ru, T., Wang, L., Xing, G. and Wang, J. (2012).Synthesis and performance of polyurethane coated urea as slow/controlled release fertilizer. Journal of Wuhan University of Technology-Mater. Sci. Ed., Vol.
27(1), 126-129.

Liu, G., Zotarelli, L., Li, Y., Dinkins, D., Wang, Q. And Ozores-Hampton, M. (2014).Controlled-release and slowrelease fertilizers as nutrient management tools. USA: US Department of Agriculture, UF/IFAS Extension Service, University of Florida, IFAS.

Milind, P. and Satbir, K. (2011). Is bottle gourd a natural guard. International Research Journal of Pharmacy, Vol. 2(6), 13-17.

Shaviv, A. (2001).Advances in controlledrelease fertilizers.pp: 1-49.

Shoji, S., Delgado, J., Mosier, A. and Miura, Y. (2001). Use of controlled release fertilizers and nitrification inhibitors to increase nitrogen use efficiency and to conserve air and water quality. Communications in Soil Science and Plant Analysis, Vol. 32(7-8), 10511070.

Tian, C., Zhou, X., Liu, Q., Peng, J. W., Wang, W.M., Zhang, Z.H., Yang, Y., Song, H.X. and Guan C.Y. (2016).Effects of a controlled-release fertilizer on yield, nutrient uptake, and fertilizer usage efficiency in early ripening rapeseed (Brassica napus L.). Journal of Zhejiang University-Science B, Vol. 17(10), 775-786.

Wang, R. F., An, D. G., Hu, C. S., Li, L. H., Zhang, Y. M., Jia, Y.G. and Tong, Y. P. (2011). Relationship between nitrogen uptake and use efficiency of winter wheat grown in the North China Plain. Crop and Pasture Science, Vol. 62(6), 504-514.

Zhao, B., Dong, S., Zhang, J. and Liu, P. (2013). Effects of controlled-release fertiliser on nitrogen use efficiency in summer maize. PloS one, Vol. 8(8), e70569. 
How to cite this article:

Jomel Sebastian, Samir E. Topno and Prasad, V. M. 2021. Effect of Controlled Release Fertilizer on Growth, Yield and Quality of Bottle gourd (Lagenaria siceraria Mol.) under Prayagraj Agro-climatic Conditions. Int.J.Curr.Microbiol.App.Sci. 10(04): 257-262. doi: https://doi.org/10.20546/ijcmas.2021.1004.026 